Morgan, A. F. (1931). F. biol. Chem. 90, 771.

Neurath, H., Greenstein, J. P., Putnam, F. W. \& Erickson, J. O. (1944). Chem. Rev. 34, 157.

Nielsen, E. \& Elvehjem, C. A. (1941). Proc. Soc. exp. Biol., N.Y., 48, 349.

Osborne, T. B. \& Mendel, I. B. (1917). 7. biol. Chem. 32, 369.

Osborne, T. B. \& Mendel, L. B. (r919). F. biol. Chem. 37, 557.

Osborne, T. B., Mendel, L. B. \& Ferry, E. L. (1919). F. biol. Chem. 37, 223.

Parsons, H. T. (1931). F. biol. Chem. 90, 35 I.

Rosenberg, H. R. (1942). Chemistry and Physiology of the Vitamins. New York: Interscience Publishers Inc.

Salmon, W. D. (1947). F. Nutrit. 33, 155.

Seegers, W. H. \& Mattill, H. A. (1935). F. Nutrit, ro, 271.

Shrewsbury, C. L., Vestal, C. M. \& Hauge, S. M. (1932). F. agric. Res. 44, 267.

Smuts, D. B. \& Marais, J. S. C. (1940). Onderstepoort F. vet. Sci. 15, 225.

Snedecor, G. W. (1946). Statistical Methods Applied to Experiments in Agriculture and Biology, $4^{\text {th }}$ ed. Ames, lowa: The Iowa State College Press.

Spitzer, R. R. \& Phillips, P. H. (1946). Proc. Soc. exp. Biol., N.Y., 63, го.

'Student' (1908). Biometrika, 6, I.

'Student' (1925). Metron, 5, 105.

Thomas, K. (1909). Arch. Anat. Physiol., Lpz., Phsiol. Abt. p. 219.

Traill, D. (1950). Chem. \& Ind. p. 23.

White, A. \& Beach, E. F. (1937-8). F. biol. Chem. 122, 2 19.

Yates, F. (1933). Emp. F. exp. Agric. 1, 129.

\title{
The Energy Metabolism of Man During Overfeeding
}

\author{
BY H. N. MUNRO \\ Department of Biochemistry, University of Glasgow
}

(Received 31 May 1950)

Studies on man show that a considerable retention of nitrogen occurs when healthy human subjects on adequate diets receive additional carbohydrate (Cuthbertson \& Munro, 1937; Cuthbertson, McGirr \& Munro, 1937; Basu \& Basak, 1939), or additional fat (Cuthbertson \& Munro, 1937), or a supplement consisting of protein, fat and carbohydrate (Cuthbertson, McCutcheon \& Munro, 1937a,b). Retention of nitrogen has also been observed in other species when they receive surfeit carbohydrate (Hoppe, 1856; Voit, I869 $b$; Larson \& Chaikoff, I937; Lathe \& Peters, 1949), or surfeit fat (Voit, $1869 a$ ). The common factor in these experiments appears to be the excessive intake of energy, and it is therefore of some theoretical interest to know whether nitrogen retention due to surfeit feeding is accompanied by an increase in basal energy metabolism.

Treichler \& Mitchell (194I) and Mukherjee \& Mitchell (1949) have established that an increase in the total food intake of the adult rat leads to a significant rise in basal metabolic rate, but the evidence for man is less satisfactory. As Krauss \& Küppers (1931) point out in a review of this field, most of the experiments involving overfeeding have been made on previously undernourished subjects. 'There are, however, three experiments in the literature carried out on healthy adults. Müller (IgII) gave a student a diet rather low in protein and energy content (39 Cal./kg. body-weight) and then raised the subject's energy intake to $275^{0}-3000 \mathrm{Cal}$, chiefly through a very considerable increase in his protein intake. During the 28 days of this surfeit diet $210 \mathrm{~g}$. 
nitrogen were retained. Calculations based on Müller's data show that the basal metabolic rate per square metre of body surface rose by about $3-4 \%$ during the last 2 weeks of surfeit feeding as compared with the values found during the pre-surfeit diet. It did not, however, rise above the values found when the subject was on a freely chosen diet before the experiment, and it is probable that the values on the presurfeit diet were unduly low because the diet was inadequate. The significance of the small rise in metabolic rate is therefore doubtful. On the other hand, Kleitman (I926) studied a healthy man on various diets and concluded that a high intake of energy, especially when accompanied by a high protein intake, has a decided influence on basal metabolic rate. His subject had previously been used in studying the effects of fasting on metabolism, but had regained his normal weight and basal metabolic rate before the experiments under consideration were begun. His basal metabolism on his normal intake of food did not vary much from $1500 \mathrm{Cal} . / 24 \mathrm{hr}$. On increasing the energy content of his diet to $3200-3850 \mathrm{Cal}$., his basal metabolism rose to $1625 \mathrm{Cal}$./day. A diet rich in protein but low in energy increased his basal metabolism to $1664 \mathrm{Cal} . /$ day, and a diet providing an excessive amount of both protein and energy resulted in a daily basal metabolism of $1914 \mathrm{Cal}$. Data on which to base calculations of surface area are not given but the weight changes recorded do not suggest that alterations in surface area account for a significant part of the results. The third investigation is described by Wiley \& Newburgh (193I), who used an unusually thin, but healthy, young adult man as subject. He first received a diet providing $3000 \mathrm{Cal}$./day, then a diet with $5000 \mathrm{Cal}$./ day; the protein intake was kept constant. During the period of surfeit feeding the basal metabolic rate rose by about $5 \%$, even after allowing for the subject's relatively greater surface area; the authors point out, however, that this was accompanied by a rise in respiratory quotient and suggest that the subject was probably not in the postabsorptive state at the time of the determinations. 'Total daily energy metabolism, as measured by insensible loss of weight, did not reveal any increased energy turnover beyond the expected specific dynamic effect of the extra carbohydrate and fat contained in the surfeit food.

From these three experiments it is evident that there is disagreement about the effect of surfeit feeding on the energy metabolism of healthy men; one indicated a very definite increase in basal energy output, and the other two a slight rise of dubious significance in metabolic rate. During a series of surfeit-feeding experiments carried out in this laboratory some years ago (Cuthbertson et al. 1937a,b), measurements of basal metabolic rate were made on one of the subjects but were not published with the other results. In view of the need for further information about energy metabolism during surfeit feeding, it seems worth while to record these findings.

\section{EXPERIMENTAL}

Full details of the conditions under which the experiments were carried out are given in the original publications (Cuthbertson et al. 1937a,b). The measurements of metabolism during overfeeding were all made on the author of this paper (subject no. 6 of the original publications), then 20 years of age, some $6 \mathrm{rgg}$. in weight and $166 \mathrm{~cm}$. in height. Four overfeeding experiments were performed on this subject. In each he 
first took an adequate diet (basal diet) for about 8 days. Food providing extra energy was then added to this diet for periods of from 5 to 15 days, and finally the subject returned to the unsupplemented basal dict for several days. 'The basal diet used was the same in all four experiments and provided $12 . \mathrm{I}$ g. nitrogen and some 2850 Cal. 'The superimposed sources of energy were respectively raw milk, boiled milk, meat with lactose and butter, and a soya-bean preparation with lactose and butter. Each surfeit preparation provided daily $36 \mathrm{~g}$. protein, $39 \mathrm{~g}$. fat, $46 \mathrm{~g}$. carbohydrate and $680 \mathrm{Cal}$. 'The surfeit food was given with the breakfast of the basal diet.

Nitrogen balances were determined from analyses of food, urine and faeces. Basal metabolic rates were estimated daily before breakfast. After the subject had relaxed for half an hour, expired air was collected in a Douglas bag and analysed in the Haldane gas-analysis apparatus. The subject was well practised in the use of the Douglas bag, having acted as subject in a previous investigation of basal metabolism. No correction for protein metabolism was made in the calculations. However, urine collected overnight, and also urine collected during the first $3 \mathrm{hr}$. after breakfast, showed that the maximum daily variation in nitrogen output at the time of the determinations of basal metabolic rate could not have exceeded $0.15 \mathrm{~g}$. nitrogen/hr.; according to Weir (1949) this would involve an adjustment of only $0_{3} \mathrm{Cal}$. in the estimate of basal heat output per hour.

\section{RESLILTS}

The changes in body-weight, in respiratory quotient, in basal metabolic rate and in nitrogen balance during the four surfeit experiments are given in Figs. 1-4. In each instance, the addition of the surfeit to the basal dict resulted in an increase in weight and in a marked retention of nitrogen. As a result, although nitrogen balance was already slightly positive on the basal diet, it became much more so during the period of surfeit feeding. Even in the third experiment, in which meat, lactose and butter were superimposed for 15 consecutive days, there was still an appreciable retention of nitrogen at the end of this period. A considerable part of the nitrogen retention must be attributed to the excessive energy intake and not to the increased protein intake, which, in the absence of an increment in energy intake, only results in a very temporary improvement in nitrogen balance (Magnus-Levy, 1907).

There were no changes in respiratory quotient or in basal metabolic rate as a result of surfeit feeding. In the first two experiments there was a general tendency for basal metabolic rate to decline throughout the experiment, but this was not apparent in the other two. In none of the studics was there evidence that the surfeit food intake stimulated basal metabolism. It should be added that variations in calculated surface area did not exceed $1 \%$ during any one experiment, so that almost the same graphs are obtained if changes in surface area due to changes in body-weight are ignored. 'The occasional large fluctuations in metabolic rate, at times down to less than 30 Cal./sq.m. body surface/hr., are not due to technical errors; on some of these occasions measurements of the specific dynamic action of the breakfast were made using the depressed basal value as a basis for calculation, and results were obtained comparable with those recorded on days when basal metabolic rate was normal. 
There was no apparent relationship between nitrogen balance on individual days of the surfeit diet and basal metabolic rate at the end of the corresponding $24 \mathrm{hr}$. period (Fig. 5).

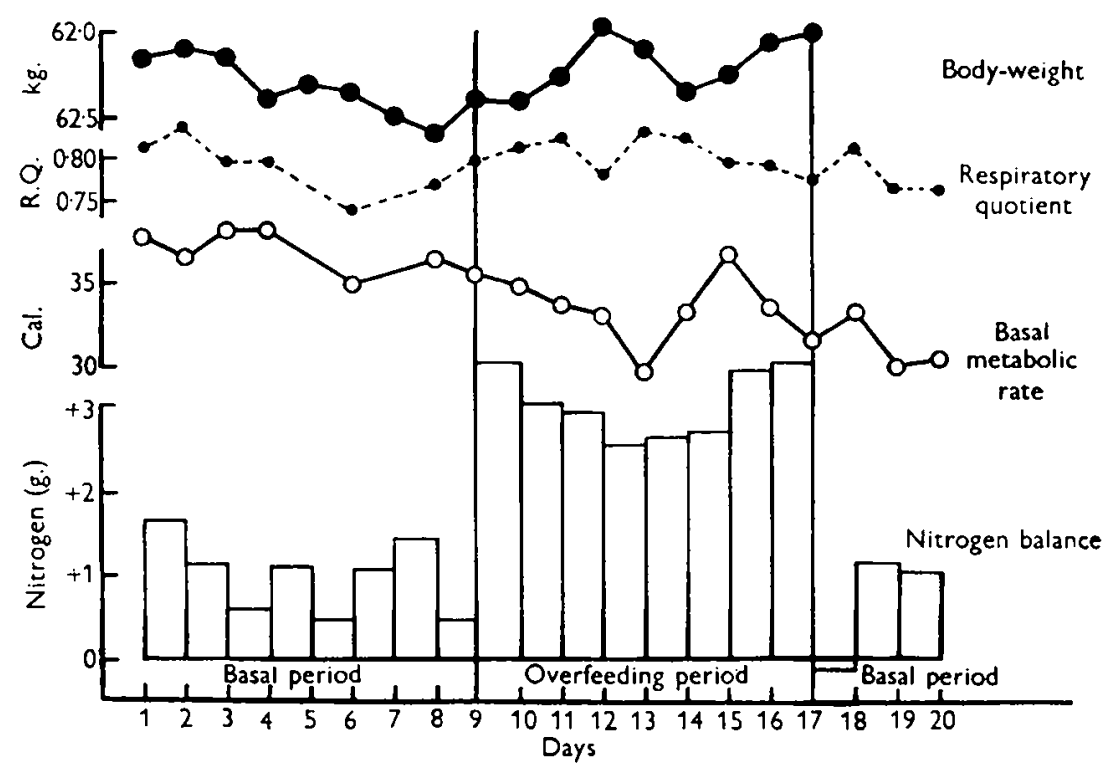

Fig. I. Changes in body-weight, in respiratory quotient, in basal metabolic rate and in nitrogen balance when 1 1. raw milk was added daily to the basal diet of a young adult man.

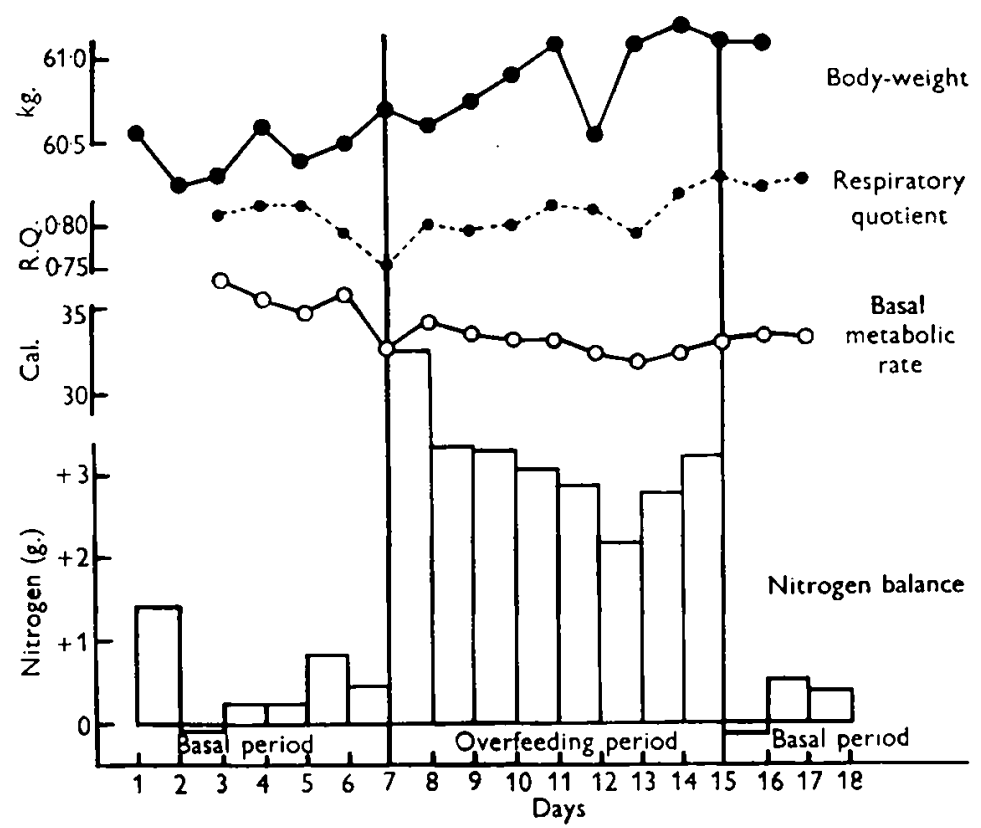

Fig. 2. Changes in body-weight, in respiratory quotient, in basal metabolic rate and in nitrogen balance when 11 . boiled milk was added daily to the basal diet of a young adult man. 


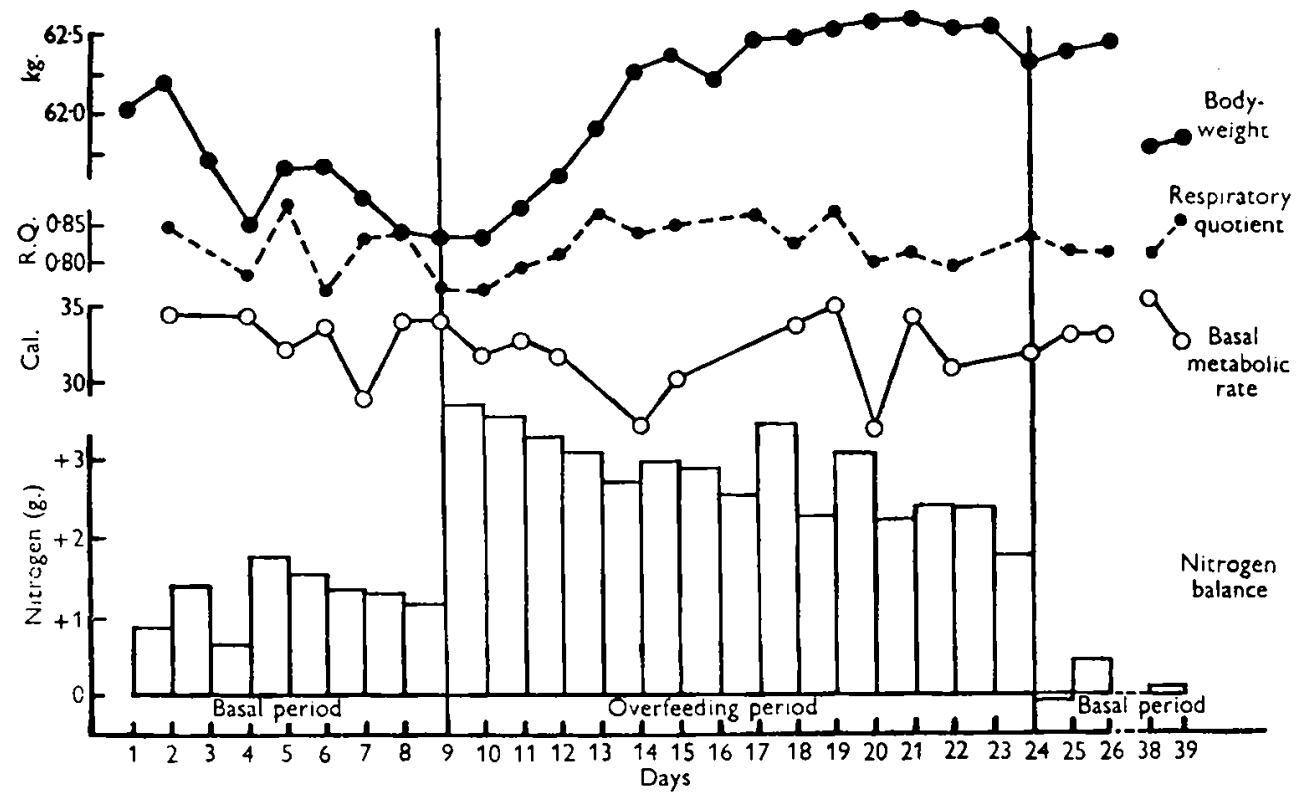

Fig. 3. Changes in body-weight, in respiratory quotient, in basal metabolic rate and in nitrogen balance when meat, lactose and butter were added daily to the basal diet of a young adult man.

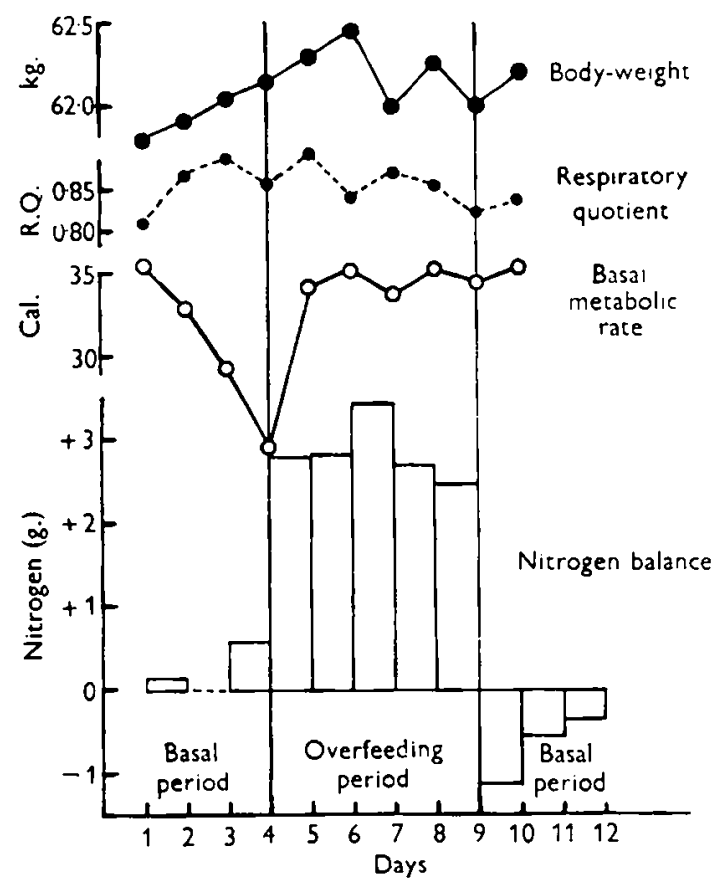

Fig. 4. Changes in body-weight, in respiratory quotient, in basal metabolic rate and in nitrogen balance when a soya-bean preparation, lactose and butter were added daily to the basal diet of a young adult man. 


\section{DISCUSSION}

It is apparent that, in the series of experiments reported in this paper, surfeit feeding was not accompanied by any increment in basal energy metabolism. There was no evidence of even the small rise reported by Müller (IgI I) and by Wiley \& Newburgh (193I). 'The results are even further out of line with the large changes recorded by Kleitman (1926). 'The question arises whether constitutional differences between the

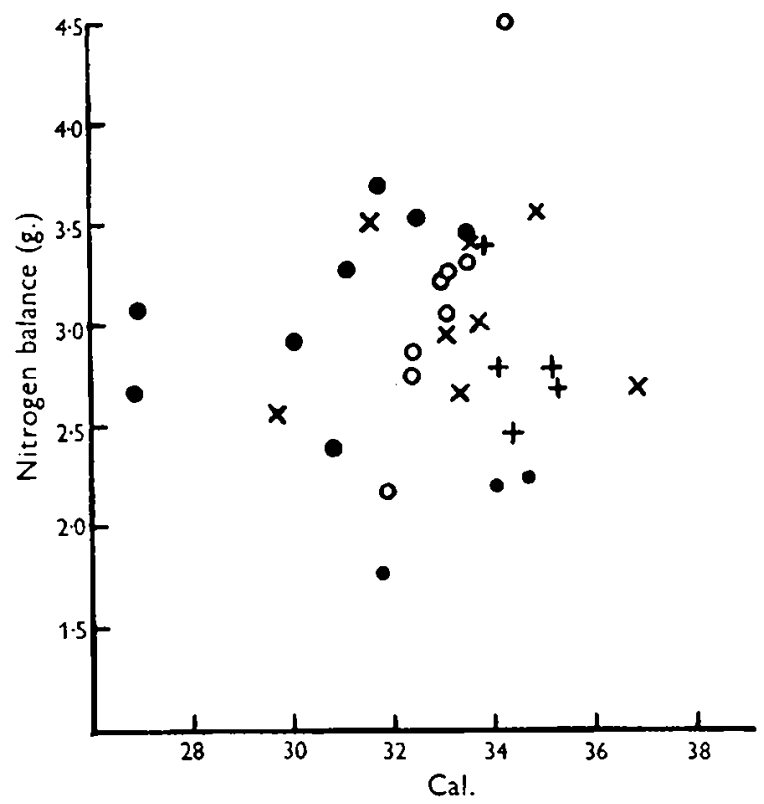

Fig. 5. The relationship between nitrogen balance and basal metabolic rate of a young adult man during periods of overfeeding. $\times$, when raw milk was added to the diet; $O$, when boiled milk was added to the diet; $\bullet$, when meat, lactose and butter were added to the diet; + , when a soya-bean preparation, lactose and butter were added to the diet.

subjects may account for their different responses to the rise in energy intake. This view was especially favoured by Grafe (1923), who believed that normal subjects react to overfeeding by an increase in metabolism and that obesity represents a failure of this mechanism. Grafe's evidence for this view has been severely criticized by others (e.g. Newburgh, 1944). It may be noted that Wiley \& Newburgh's (1931) subject was habitually lean, but did not respond to extra food with an increase in energy metabolism; instead he put on weight.

The failure to find a relationship between basal energy metabolism and nitrogen balance during surfeit feeding may seem at first sight to be out of line with the frequent association of parallel changes in the metabolism of protein and energy. In the first place, there is a constant relationship between endogenous nitrogen output and basal metabolism among adults of different species (Terroine \& Sorg-Matter, 1927; Brody, Procter \& Ashworth, 1934; Smuts, 1935). In the second place, undernutrition leads to a loss of nitrogen from the body and to a decline in basal metabolism. Replacement of 
this lost tissue by adequate diets is accompanied by a rise in basal metabolism (Lusk, 192I). Finally, the growing animal shows both a retention of nitrogen and a high basal metabolic rate. In none of these instances, however, do protein metabolism and energy metabolism appear to be causally related. 'I'reichler \& Mitchell (I94I) have shown for the rat that exposure to a cold environment raises endogenous nitrogen output without elevating basal metabolism, and conversely that basal metabolism, and not endogenous nitrogen metabolism, is affected by an increased food intake. It is thus probable that, in different species, basal metabolism and endogenous nitrogen output are related through a common factor, such as surface area. As regards undernutrition, lusk ( 192 I) has pointed out that the depression of basal metabolism is out of all proportion to the loss of body protein which occurs, and Beattie, Herbert \& Bell (1947) could find no causal relationship between basal heat production and nitrogen retention in a group of subjects recovering from undernutrition. Hamilton (1939) investigated the factors affecting basal metabolic rate in the growing rat and was unable to relate basal metabolism to the protein content of the diet, to rate of growth or to the composition of the rat carcass. 'I he association between protein metabolism and basal heat output would thus appear to be a superficial one.

\section{SUMMARY}

1. Basal metabolic rate and nitrogen balance were studied in four experiments on one human subject.

2. A mixture of protein, carbohydrate and fat (energy value $680 \mathrm{Cal}$.) was superimposed on an adequate basal diet.

3. In none of the experiments was there any evidence of a rise in basal metabolism, although the surfeit feeding lasted for $5^{-1} 5$ days and caused considerable retentions of nitrogen.

\section{REFERENCES}

Basu, K. P. \& Basak, M. N. (1939). Indian F. med. Res. 27, 115.

Beattie, J., Herbert, P. H. \& Bell, D. J. (1947). Brit. F. Nutrit. 1, 202.

Brody, S., Procter, R. C. \& Ashworth, U. S. (1934). Res. Bull. Mo. agric. Exp. Sta. no. 22.

Cuthbertson, D. P., McCutcheon, A. \& Munro, H. N. (1937a). Biochem. F. 31, 681.

Cuthbertson, D. P., McCutcheon, A. \& Munro, H. N. (1937b). Biochem. $\mathcal{~ f . ~ 3 1 , ~ 6 8 9 . ~}$

Cuthbertson, D. P., McGirr, J. L. \& Munro, H. N. (1937). Biochem. F. 31, 2293.

Cuthbertson, D. P. \& Munro, H. N. (1937). Biochem. F. 31, 694.

Grafe, E. (1923). Ergebn. Physiol. 21, I.

Hamilton, T. S. (1939). $\mathcal{~ F . ~ N u t r i t . ~ 1 7 , ~ S u p p l . , ~ p . ~ I 3 . ~}$

Hoppe, F. (1856). Virchows Arch. 10, 144.

Kleitman, N. (1926). Amer. F. Physiol. 77, 233.

Krauss, E. \& Küppers (193I). Z. klin. Med. 118, 64.

I.arson, P. S. \& Chaikoff, I. L. (1937). F. Nutrit. 13, 287.

Lathe, G. H. \& Peters, R. A. (1949). Quart. F. exp. Physiol. 35, 157.

Lusk, G. (1921). Physiol. Rev. I, 523.

Magnus-Levy, A. (1907). In v. Noorden's Metabolism and Practical Medicine. [I. W. Hall, editor.] London: Heinemann.

Mukherjce, R. \& Mitchell, H. H. (1949). F. Nutrit. 37, 303.

Müller, A. (191 I). Zabl. ges. Physiol. Path. Stoffw. 6, 617.

Newburgh, L. II. (1944). Physiol. Rev. 24, 18.

Smuts, D. B. (1935). F. Nutrit. 9, 403.

Terroine, E. F. \& Sorg-Matter, H. (1927). Arch. int. Physiol. 29, 121. 
Treichler, R. \& Mitchell, H. H. (I94I). F. Nutrit. 22, 333.

Voit, C. (1869a). Z. Biol. 5, 329.

Voit, C. $(1869 b)$. Z. Biol. 5, 431 .

Weir, J. B. de V. (1949). F. Physiol. rog, I.

Wiley, F. H. \& Newburgh, L. H. (1931). J. clin. Inzest. ro, 733.

\title{
Variations in the Pigment and Vitamin A Contents of Egg Yolk
}

\author{
By F. H. GRIMBLEBY AND D. J. G. BLACK \\ University of Reading
}

(Received I Yune 1950)

The first real contribution to our knowledge of the composition of the yolk pigments was made by Thudichum ( 1869 ), who showed that the yellow pigment of egg yolk was fat-soluble and unsaponifiable. He demonstrated the similarity between this pigment, which he called 'luteine', and the pigments of butter, corpus luteum and plant materials. Later Schunck ( 1903 ) compared the absorption spectrum of yolk pigment with those of a number of other naturally occurring pigments, and showed that the pigment was identical with leaf xanthophyll but different from carotene. Willstatter \& Escher ( $\mathrm{I}$ I I I), using over a thousand eggs, prepared $4 \mathrm{~g}$. crystalline pigment and determined its formula, which they found identical with that of leaf xanthophyll, $\mathrm{C}_{40} \mathrm{H}_{58} \mathrm{O}_{2}$, but they could not decide that the two substances were identical and eventually concluded that they were isomers. These same workers isolated a small quantity of a second pigment, which they identified as carotene. More recently, experiments by Gillam \& Heilbron (1935) have shown that at least three pigments are present in normal yolks. The one present in greatest amount was xanthophyll, and the others were identified as cryptoxanthin and $\beta$-carotene. Researches by Kuhn, Winterstein \& Lederer (193I) have shown that the so-called xanthophyll is a mixture of lutein and zeaxanthin in the ratio of $7: 3$, so that at the present time the yolk pigments are regarded as a mixture of lutein and zeaxanthin, usually referred to as xanthophyll, with much smaller quantities of cryptoxanthin and $\beta$-carotene.

The exact physiological significance of some of the yolk pigments is still undecided. Capper, McKibbin \& Prentice (1931) found that vitamin A in the diets of chickens could be wholly replaced by $\beta$-carotene and that, as $\beta$-carotene was converted rapidly to vitamin $A$, it did not cause pigmentation of the beaks and shanks. Experiments by Palmer \& Kempster (1919) have indicated that fowls can be raised on a diet containing vitamin A but no xanthophyll, that absence of carotenoids from the diet from hatching to maturity has no effect on fecundity, and that the transference of carotenoid pigments to the yolk during laying is simply an excretory process replacing the process of accumulation and oxidation of the pigments in the skin of the fowl during a period of non-laying. Palmer \& Kennedy (1921), after giving a carotenoid-free diet to hens until colourless yolks were produced, found that subsequent pigment-free eggs produced healthy chicks, and Plimmer, Rosedale \& Raymond (1923) concluded from their own 